\title{
An Archaeological Identity of the Majimaji: Toward an Historical Archaeology of Resistance to German Colonization in Southern Tanzania
}

\author{
Nancy A. Rushohora \\ Department of Anthropology and Archaeology, Faculty of Humanities, \\ University of Pretoria, Hatfield, Pretoria 0083, South Africa \\ E-mail: nrushohora@gmail.com
}

\begin{abstract}
This paper presents new insights on the Majimaji war, which is one of the least studied topics in Eastern Africa's colonial history. The Majimaji (19051907) was a large scale war of resistance against German colonial rule in Tanzania. This war started in the Lindi Region and spread rapidly to other areas of southern Tanzania. It was primarily a reaction to the exploitative nature of German colonial rule. The archival records that exist are biased toward German sources and information supplied by their African agents who wished to please the colonists and spare their lives. Although local oral histories on the war existed, this has been poorly documented or the accounts have been lost. In this circumstance, archaeology provides an alternative source of evidence about the Majimaji war. This paper presents the intellectual arguments that underpin this research. It explains why archaeology is still important to study popular historical events. Using archaeology, the Majimaji battle sites can be identified and documented so as to enhance understandings of the war and to fill in gaps that arise from the limitations of documentary archival records and oral histories. In addition, this research has elicited public awareness and perception of the battle sites and obtained new insights into how the memories of the war resonate in people's minds.
\end{abstract}

Résumé: Cet article présente de nouveaux éclairages sur la guerre Maji-Maji, qui est l'un des sujets les moins étudiés de l'histoire coloniale de l'Afrique orientale. La guerre Maji-Maji (1905-1907) fut une guerre de résistance à grande échelle contre le pouvoir colonial allemand en Tanzanie. Elle commença dans la région de Lindi et s'étendit rapidement à d'autres régions du sud de la Tanzanie. Elle fut avant tout une réaction à l'exploitation du pouvoir colonial allemand. Les documents d'archives qui existent font la part belle aux sources allemandes et aux informations fournies par leurs agents africains, qui souhaitaient satisfaire les colons et 
sauver leur vie. Bien qu'il existât des histoires orales locales sur la guerre, elles furent mal documentées ou les récits furent perdus. L'archéologie offre, en pareil cas, une autre source d'éléments probants sur la guerre Maji-Maji. Cet article présente les arguments intellectuels qui soutiennent ces recherches. II explique pourquoi l'archéologie est essentielle pour l'étude des évènements historiques populaires. À l'aide de l'archéologie, les sites de batailles des Maji-Maji peuvent être identifiés et documentés afin d'améliorer la compréhension de la guerre et combler les lacunes découlant des limites des documents d'archives documentaires et des histoires orales. En outre, ces recherches suscitèrent la sensibilisation du public et la perception des sites de batailles et obtinrent de nouvelles connaissances sur la façon dont les souvenirs de la guerre sont évoqués dans les esprits.

Resumen: El presente documento presenta nuevas perspectivas sobre la guerra de Maji Maji, que es uno de los temas menos estudiados de la historia colonial del África Oriental. La Maji Maji (1905-1907) fue una guerra de resistencia a gran escala contra el régimen colonial alemán en Tanzania. Esta guerra se inició en la Región de Lindi y se extendió rápidamente a otras áreas del sur de Tanzania. Fue fundamentalmente una reacción a la naturaleza explotadora del régimen colonial alemán. Los registros de archivos que existen están sesgados a favor de las fuentes alemanes y la información suministrada por sus agentes africanos que deseaban complacer a los colonialistas y salvar sus vidas. Aunque existían las historias orales locales sobre la guerra, han sido mal documentadas o se han perdido los informes. En estas circunstancias, la arqueología proporciona una fuente alternativa de pruebas sobre la guerra de Maji Maji. El presente documento presenta los argumentos intelectuales que respaldan esta investigación. Explica por qué la arqueología sigue siendo importante para estudiar acontecimientos históricos populares. Mediante la utilización de la arqueología, los emplazamientos de la batalla de Maji Maji pueden ser identificados y documentados con el fin de mejorar la comprensión de la guerra y llenar las brechas que surgen de las limitaciones de los registros de archivos documentales e historias orales. Asimismo, la presente investigación ha suscitado la concienciación pública y la percepción de los emplazamientos de la batalla y ha obtenido nuevas perspectivas sobre cómo los recuerdos de la guerra resuenan en las mentes de las personas.

\section{KEY WORDS}

Majimaji, Identity, Memory, Heritage, Resistance, Southern Tanzania 


\section{Introduction and Nomenclature}

The colonization of Tanzania resulted from the Berlin Conference of 18841885 which partitioned Africa into different European spheres of control or influence (Herbst 1989:674). German East Africa was the largest German colony with over $1,235,976 \mathrm{~km}^{2}$ in extent covering Tanzania and the island of Mafia (Iliffe 1979). By the time Europeans were eager to acquire colonies, they were novices to colonial power thus, received numerous resistances (Pesek 2007). The Germans ignorance of local customs, unwitting indignities meted out to chiefs and harsh military reactions were not accepted by the local population. The Majimaji war was a response to German harsh treatment, taxation, forced labor and land alienation which accompanied the German colonialism in Tanzania.

The Majimaji war initial battlefield was at Nandete among the Matumbi people. The war began after two patriotic warriors namely Ngulumbalyo Mandai and Lindimyo Machela uprooted three cotton plants from the German colonial plantation. This happened 3 years after the establishment of the cotton plantation in the area. The cotton plantation economy was not beneficial to the southern Tanzanian people because of the harsh and inefficient way in which the scheme was handled. Hardship and suffering was caused and the scheme did not benefit the local people. Although the war was initiated by one ethnic group, more than twenty tribes joined the resistance with the interest to fight the Germans. The Majimaji war spread from the Matumbi to Luguru, Mahenge, Lukuledi, Kilombero valley, Songea and Njombe. The warriors were bounded together by rituals and traditions. A medicine man, known as Kinjekitile Ngwale, living at Ngarambi, west of Kipatimu, declared that by sprinkling people with medicinal water (maji) he could provide them with immunity against the Germans bullets. However, the medicine was ineffective and more than 100,000 people died.

The term maji (Kiswahili term for water) originated from Kinjekitile Ngwale who was the ritual leader of the Majimaji war. Kinjekitile provided charmed water (maji) for the people to sprinkle, bath or rub onto their bodies. The main function of the water was to turn the German bullets into water (Gwassa 1973). Given the peoples fear of the German, maji gave people the morale to engage in the war. Although it did not provide any immunity, maji served as a unifying factor and remained important throughout the war. It is from this concept that Majimaji war acquired its name (Figure 1).

Linguistically, the term Majimaji is an exocentric compound formed by two identical elements maji maji. Since its acquisition, the term has been used by historians without destruction of its etymology (Maji Maji) to perpetuate the original cry that the Majimaji warriors made, yet pronounced 


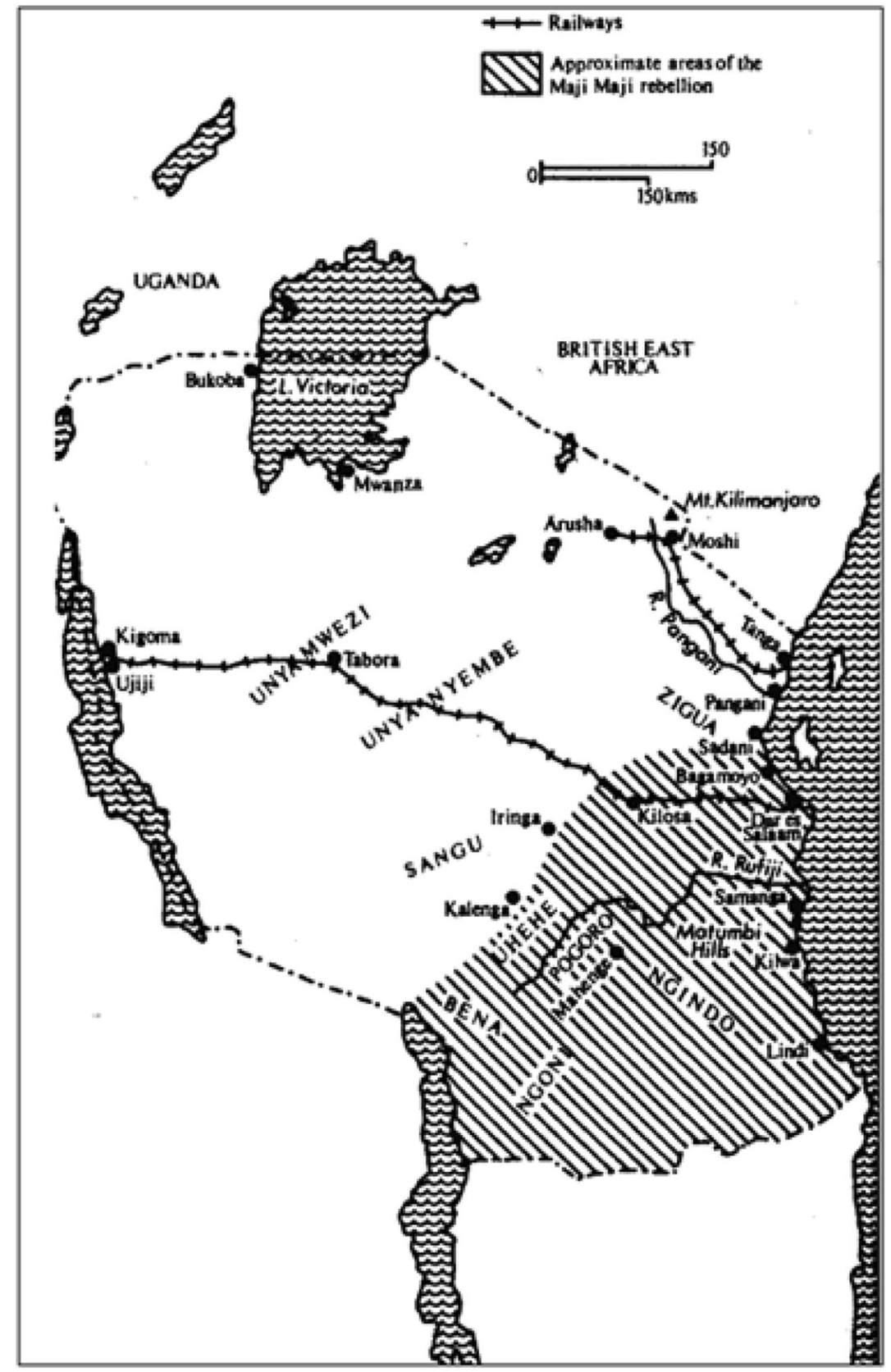

Figure 1. The map of Tanzania showing the are covered by the Majimaji war (Tidy and Leeming 2001) 
as a compound Majimaji. Scholars, such as Becker (2004) and Mapunda (2010), use the term as two separate entities_Maji Maji. Ebner (2009) has used the term as a single word Majimaji although without giving a detailed account as to why he did so. Swahili literature views it differently, and enters it as a single unit as it is pronounced, Majimaji. Languages orthography and pronunciation aspects are different while in others the two are the same (Lyons 1968; Malande 2011). English serves as a good example of the former, Swahili of the later. English orthography is not consistent in representing compounds since they are sometimes written as single words, sometimes with an intervening hyphen and sometimes separate words (O'Grady et al. 1996). Yet, rules for forming compounds differ from language to language (Njogu et al. 2006; Ombuchi and Mukhwana 2010). Language is a symbol and identity of the bearers. Majimaji as a term retains the Swahili meaning and identity. It should therefore abide to the Swahili language principles. Thus, Swahili compounds are written as one word; for this case, Majimaji and not Maji Maji shall be used for this paper.

In terms of coverage, the Majimaji war spread in a very vast area of Tanzania. At times, it was assumed to cover the entire country (Alexander 2008). The war spread to over $260,000 \mathrm{~km}^{2}$ of southern Tanzania and involved more than 20 southern Tanzanian ethnic groups, such as the Ngoni, Makonde, Mwera, Ngindo, Bena, Matumbi, Pogoro and Zaramo (Gwassa 1973) in Lindi, Mtwara, Ruvuma, Morogoro, Njombe, Dar es Salaam and Pwani regions. Only Ruvuma, Lindi and Mtwara witnessed the most concerted Germany military efforts during the war. Mtwara is the immediate neighbor of Lindi thus provides an ideal setting. Ruvuma experienced the most sustained fighting during Majimaji. Its politics were also the most complex of any region involved in the war (Mapunda 2010). Thus, the intensity of the war in Ruvuma supersedes other southern Tanzania regions. Districts which were under study were chosen to include Kilwa, Lindi Rural and Urban, Liwale, Masasi, Songea Urban and Namtumbo.

\section{Rationale of the Archaeology of Majimaji War}

The factors that make the deployment of archaeology of the Majimaji war are three fold: limited historical studies; historical interpretation of the war and the Majimaji war identity. From historiographical perspective, the Majimaji war generated considerable amounts of evidence and commentary from the German military men, colonial administrators, missionaries, and African civilians; all left records of what they observed during the war (Moyd 2010). However, Majimaji has remained the least studied topic in 
the history of Tanzania. Historians such as Giblin and Monson (2010:3) think that "the book had been closed too soon". This is because some of the groups including women, children, non-combatants, Arabs, Indians and Christians who were also affected by the war have completely been neglected. Further, there are contrasting interpretations of Majimaji in historical records which include German records, the work of nationalist historians and post-1990s Majimaji scholars, as explained below.

German records depict the Majimaji as against colonialism. The Majimaji is documented as part of a long series of wars (Beez 2004). German records of the Majimaji equate the war with other ethnic wars which were dominant in Africa prior to the advent of colonialism. They advance the argument that the warriors not only savagely attacked Europeans, but also Arabs, Indians and Swahili as well. The Governor, Graf von Götzen labeled the movement irrational (Greenstein 2010). The classical colonial account which was written was apologetic, unreliable and a defence of colonial policies (Bell 1950). Following the outbreak of the Majimaji in 1905, German colonial policy makers created an interpretation of events leading up to the war, which was published as a Denkschrift (memorandum) for a parliamentary and public readership, five months after the outbreak. The Germans reports of the war were for only official war reports appear in German Press. The official reports had some intentional omissions or additions for the defence of Germans political matters (Stollowsky and East 1988).

Nationalist historians studied the Majimaji war immediately after independence and the establishment of the University of Dar es Salaam in early 1960s. The nationalist interprets the war as a large scale fight for freedom from German rule. Kinjekitile Ngwale is commemorated as a hero who managed to unite over 20 largely different ethnic groups in southern Tanzania to fight a common foe (Gwassa and Illife 1969). Tanzanian nationalists used the Majimaji as an example of the first stirrings of Tanzanian nationalism; a unifying experience that brought together all the different peoples of Tanzania under one leader in an attempt to establish an independent nation free from foreign domination. The war was used during the Tanganyika National Union (TANU) (the political party which gave freedom to Tanzania) conferences to stir the unity agenda (Nyerere 1967). Many postcolonial African states desired to build up legitimacy of their pre-colonial histories (Lane 2011). This include also pedagogy, to bring a sense of patriotism for the country historical narratives (Lawi 2009:66).

In the post-1990s Majimaji scholars criticize the nationalist historians. Nationalists conducted the Majimaji studies soon after independence which impacted their interpretation (Sunseri 1999). After the establishment of Majimaji as war of independence, Majimaji studies in Tanzania went completely out of fashion. The interpretations of the Majimaji war since 1990s have therefore been done as a critique of nationalist and German colonial 
perspectives. These scholars elucidate that Majimaji resulted from multivariate factors. The German accounts created conflicting views of the origins of the war and attempt to defend the colonial hegemony (Sunseri 1999) the nationalist historians neglected those aspects of the war that did not conform to a vision of unity (Becker 2004; Giblin and Monson 2010; Monson 1998, 2010; Sunseri 1999). These factors include gender struggle, the role of hunters, religion and medicine.

By viewing group and culture as coterminous, mutually constituting relatively enduring and located in a bounded space (Linger 2005:188). However, the Majimaji war occurred were social identities had been fashioned by the colonial system and a bureaucratic system of classification. In any colonial conquest, the first objective was to capture what the local inhabitants prize the most; not surprising colonial military campaigns were directed at wounding the sense of patriotism, honour and economic self-esteem (identity) of the colonized (Kamanga 2009). In this case, narratives of the Majimaji war classified the same dichotomy the local peoples are suffering from recovery and emerging from past characterized by competing and contradictory histories in attempt to build a new sense of nationhood and belonging (Scheper-Hughes 2005).

One of the obscured identities of the war lies in the war logistics. The sophisticated organization of the war has led to the acknowledgement of different authorities as the master minds of the war in attempt to disqualifying African identity. The Arabs, Muslims, Missionaries and German allies are attributed to be the African associates in planning of the war. Herr Eduard Haber, the then German chief secretary in German East Africa that the development of the Majimaji was controlled in a logical manner by aged strategists. Suspects that discharged askari (police) were behind it while others point to an Arab as the leader (Gwassa 1969:256). Yet Haber was unable to explain why and how discharged askari or an individual Arab could have decided to fight against the Germans and how they or he could mobilize such a vast population. Sunseri (2010) is of the opinion that hunters were the planners and leaders. This is because they had knowledge of terrain and landscape, the use of medicine in their hunting carriers and hunting like the Majimaji war was attached to taboos.

The Majimaji combined a lot of beliefs (Monson 2010:68). These ideologies have been interpreted differently, making the identity of the war contested. The practices of the war have been attached to alien religious ideologies such as Christianity and Islam in contrast to African traditional religion or Paganism. Colonial administrators such as Gotzen reckoned the war the last fling of African paganism against Christian culture of Germany (Gwassa 1973). This is because the African pattern of resistance during Majimaji was very complex (Gwassa 1969). The first outbreak of the Majimaji war was in Matumbiland. Missionaries had never been settled. The 
first mission in Matumbiland was established in 1910 at Kipatimu. In Liwale which is another familiar Majimaji battle site, no mission station existed until 1964. In Ngarambi which was the origin water medicine there is no established mission and missionaries. However, in some places the missionaries had been so successful that converts tended to be against the Majimaji war and support the missionaries when attacked. This happened in Masasi. An interview with a retired abbot H. Siegfried of the Benedictine congregation revealed that missionaries avoided any association with the German administrators. Thus, the choice of their Christian stations in the interior other than the coast was an attempt to avoid such an encounter. Yet missionaries behaved like the German colonial officials and in others they contravened traditional religion, all of which provoked hostility since they were then seen as an extension of the colonial rule (Mapunda 2010). Moreover, it was very difficult to separate missionaries from the colonial government because the colonial government officials and missionaries were all whites/Europeans. Both had guns in their possession and colonial government official sometimes enjoyed taking leave in the missionaries' premises/houses. This confused the local people and they failed to differentiate one's role from the other.

The contemporary Islamic communities account for the Majimaji as a Jihad-a Muslim holy war against the non-Muslim European communities (Abdalah 2011). The Islamic nature of the war is emphasized by the fact that the prominent Majimaji warriors and leaders were Muslims. Tanzania under the influence of the Arabs between 1840s and 1885 before the European conquest. The Arabic rule coincided better with the African culture because it did not interfere with the Africans ways of life. Islamic culture acquired a social status especially among the African elites and coastal peoples. As the result, most of the Arabs were not the target of the war by the Majimaji fighters unless traders or associates of the German colonization Muslims were seen at the time of the conflict as traders and these were the target of the war (Larson 2010). Mission stations and churches were plundered and set fire together with the colonial government headquarters, stations and German. Despite the fact that mosques existed within Majimaji area, none of them attacked during the war. Considering the Majimaji war Islamic identity is perplexing. The pattern of the war ideology can be attributed to the role of individual agency rather than denomination. Individual Muslims joined the Germans to fight against the Majimaji warriors. Masoud of Kikole in Ngoniland for example, fought against Chief Mputa and his slaves joined the German army during Majimaji (Mapunda 2010). In some battles, the leaders were Christians like Gabriel of Mweraland. Although many German police (askari) considered themselves Muslim, to the Germans, conduct of the war had little to do with Islam. There were Christian police in the German force, they were few (Moyd 2010). Most of 
the German askari were mercenaries from Somalia and coastal peoples who have always identified themselves as Muslims/Arabic/civilized vis a vis Africans/barbaric/pagan. Christian and Islam identities do not account for the organization of believers and unbelievers in addition to the disparities arising from the reaction of the people of the same religious belief. All these stress how understanding patterns of historical change depend on understanding the identities of social agents; and how those identities were themselves changing, either were historically transient and shifting (Johnson 2002).

One dimension of the Majimaji, then, was a material and metaphorical war between African and German hunters (Sunseri 2010:119). Hunters, particularly elephant hunters had a central role in the Majimaji war. They took the lead in opposing German forces owing to military skills and knowledge of the landscape for instance, the leader of the Majimaji war in Liwale was an elephant hunter named Abdalah Mapanda and Chief Chabruma of the Mchope Ngoni had repute as an elephant hunter (Sunseri 2010). Although prophets and medicine men were very important throughout the war, they did not act as leaders (Giblin and Monson 2010:15). People who were not recognized as leaders before the war acted as organizers and leaders in different groups. The belief in water-maji remained prominent throughout the war however nick named after the religious practices by scholars or the Majimaji peoples. For example, Nduna Songea wrote a letter to the Yao to invite them to the war and convince he sent a bottle from prophet Mohamed contain the medicine which serve to defeat the Europeans. Monson (2010:68) recount that the whole people of Ngarambi and the neighboring villages were baptized with the maji. Germans effort to trace the origin of the maji led them to the island of Zanzibar where the medicine was assumed to had been used against the British during the ouster of Seyyid Khalid in 1896 (Monson 2010:51).

History needs to be written (Jones 2002). Historical accounts are narrowed to oral and written sources. Given the fact that the materiality and landscape of the war exist, it is important to interact with the battle scene so as to establish the identity of the war. Grassroots archaeological projects on sites of colonial battlefield in Africa are rare and striking (Gilchrist 2003). Elsewhere, the archaeology of the contemporary past has shown the importance of the material remains as a source of information for bringing the recent past to the fore and evoking an interest in it (Burström 2009). Using archaeology, the Majimaji battle sites were identified and documented so as to enhance understandings of the war. The sub surface materials were also traced to establish the available remains of the war. These were attached to the archaeological ethnographies which presented the perception of the battle sites by the local communities today and provide insights into how the memories of the war resonate into people's minds. 
Without archaeology some aspects of the recent past would in many cases rest in silence and ultimately be forgotten (Burström 2009).

\section{Archaeology of the Majimaji War}

This paper presents a first attempt archaeological reconnaissance of three geographical regions affected by the Majimaji war. Similar attempts were previously conducted at a narrow scale, for example, Mapunda (2010) studies in Ngoniland and Alexander (2008) in Matumbiland. Written and ethnographic information were used to aid in identification of Majimaji battle sites which were then surveyed. Four patterns were identified as the mode of organization of the battles; date of occurrence from the first battle to the last one; the spread of the battle from one ethnic group to the other; spread of maji and the movement of the Majimaji messengers; and the administrative regions as recognized today. The dates of occurrence of the Majimaji war in different battlefields were very dynamic toward the immediate causes of the war thus the war was not spontaneous (Gwassa 1973). Dates of different battles co-exist and sometimes only a month is in record without a date.

The spread of the battle from one ethnic group to the other make another pattern. Majimaji stimulated different modes of reactions among southern Tanzania ethnic groups. Although majority of the ethnic groups in southern Tanzania joined the war, sometimes they did so without support of their rulers. A number of headmen and rulers were forced to join the war only after a threat of being killed as enemies. The leaders of the war were few. Most of the coastal peoples irrespective of their ethnicity remained militarily passive. Therefore, ethnic groups and sometimes headmen of the same ethnic group reacted differently to the Majimaji war movement. Nevertheless, majority of the people migrated beyond the Majimaji borderline. Shifting agriculture has led to the vast spread of members of this ethnic group. This has resulted in a complex web of cultural intermixture and ethnic movement of people of Southern Tanzania which led to a very difficult differentiation of ethnic group.

Another approach is that of the spread of maji agent and the movement of the Majimaji messengers. Maji was just an organizational device (Gwassa 1973). However, the acceptance and utilization of maji created a lot of ethnic confusion and variations. The receipt of maji also vary widely in due parameters. Maji spread throughout southern Tanzania prior to the war in Matumbiland. However, other war zones received maji long after the war had begun. For example, the war breakout in Matumbiland on 30 July, 1905 (Alexander 2008); on the 13 August, 1905 the war broke out in Liwale (Libaba 1968); on the 16 August 1905 in Pogoroland (Illife 1979) 
and by the end of August in Zaramoland (Sunseri 1997). The Ngoni received maji medicine and the Majimaji war; the Matumbi received maji first and initiated the war while the Yao received Majimaji war before maji medicine. The movement determined the reaction toward the war; the Yao for example, who received Majimaji before maji, resisted to join the war (Iliffe 1979). The dynamic nature of Majimaji discourages a wholesale approach toward its archaeological studies. Established administrative regions as known today were favoured as a useful pattern for data presentation. Given the fact that most of these battle sites are in form of places or battlefield landscape, the archaeology of these sites needed to answer questions like the existence of monument or memorial, the nature of landscape and type of battle site as described in Table 1.

Archaeological survey was conducted in eight districts namely; Kilwa, Lindi Rural and Urban, Liwale, Masasi, Songea Urban and Namtumbo. Survey which was informed by the local people information and written sources intended record and document the Majimaji battle sites, refuge areas and imprints of the war on the Southern Tanzania landscape. Survey was conducted on both the coastal and the littoral parts of southern Tanzania. The area over which survey was conducted was chosen on the basis of documentary sources, ethnography and pilot surveys which aimed toward detecting potential Majimaji war sites. Survey was accompanied by the mapping of battle sites, battle routes and refuge areas associated with the war. The objective was to generate an inventory of sites of the Majimaji war in southern Tanzania. Archaeological excavation, which is the systematic uncovering of archaeological remains through removal of deposits of soil and other material covering them, was conducted in two battle sites in order to test the reliability of surface data and to assist in defining the cultural identity of the Majimaji war landscape. Indestructible materials such as local and imported pottery, lithic, building materials and metal objects were collected during survey and excavation.

\section{Majimaji War Peoples}

The historical accounts of the battle landscapes above have been presented by historians such as Becker (2004), Gwassa and Iliffe (1969), Larson (2010), Monson (1998); Moyd (2010); Schmidt (2010) and Sunseri (1997). The archaeological interpretation of the materiality and battle landscape is presented to allow answering the question of identity and to present local people voices into the perception and use of the Majimaji battle sites among the present societies. Social identity is multi-scalar in nature; it can be simultaneously bind and divide at several different social scales (Adler and Bruning 2008:38). Social group identity is also historically contingent, 
Table 1 A summary of the Majimaji war battle sites

\begin{tabular}{|c|c|c|c|c|c|c|c|c|}
\hline \multirow[t]{2}{*}{ Site } & \multirow[t]{2}{*}{ Location } & \multirow[t]{2}{*}{ Region } & \multicolumn{5}{|c|}{ Battlefield landscape } & \multirow[t]{2}{*}{ Type } \\
\hline & & & $\begin{array}{l}\text { Coastal/ } \\
\text { estuarine }\end{array}$ & Hilltop & Urban & Low land & Memorial & \\
\hline Songea & $10.68^{\circ} \mathrm{S} / 35.65^{\circ} \mathrm{E}$ & Ruvuma & & & $\bullet$ & & $\bullet$ & $\begin{array}{l}\text { Hanging memorial } \\
\text { Majimaji museum } \\
\text { German boma }\end{array}$ \\
\hline Chandamali & $10^{\circ} 39^{\prime} \mathrm{S} / 35^{\circ} 39^{\prime} \mathrm{E}$ & Ruvuma & & $\bullet$ & & & & Refuge cave \\
\hline Maposeni & $10^{\circ} 35^{\prime} \mathrm{S} / 35^{\circ} 25^{\prime} \mathrm{E}$ & Ruvuma & & & $\begin{array}{l}\bullet \\
\bullet \\
\bullet\end{array}$ & - & & $\begin{array}{l}\text { Destroyed church } \\
\text { Chief residence } \\
\text { Priest death site } \\
\text { Ritual hut }\end{array}$ \\
\hline Kitanda & $9^{\circ} 58^{\prime} \mathrm{S} / 35^{\circ} 46^{\prime} \mathrm{E}$ & Ruvuma & - & & & & & Subchief residence \\
\hline Namabengo & $10^{\circ} 33^{\prime} \mathrm{S} / 35^{\circ} 51^{\prime} \mathrm{E}$ & Ruvuma & - & & & & & Battle site \\
\hline Nandete & $8^{\circ} 29^{\prime} \mathrm{S} / 38^{\circ} 56^{\prime} \mathrm{E}$ & Lindi & & $\bullet$ & & & - & $\begin{array}{l}\text { Cotton plantation } \\
\text { Refuge caves }\end{array}$ \\
\hline Lindi & $09^{\circ} 58^{\prime} \mathrm{S} / 39^{\circ} 42^{\prime} \mathrm{E}$ & Lindi & - & & - & & & German boma \\
\hline Kilwa & $8^{\circ} 45^{\prime} \mathrm{S} / 39^{\circ} 24^{\prime} \mathrm{E}$ & Lindi & - & & - & & - & German boma \\
\hline Kibata & $9^{\circ} 28^{\prime} \mathrm{S} / 38^{\circ} 58^{\prime} \mathrm{E}$ & Lindi & & $\bullet$ & & & & $\begin{array}{l}\text { Battle site } \\
\text { German boma }\end{array}$ \\
\hline Ngarambi & $8^{\circ} 28^{\prime} \mathrm{S} / 38^{\circ} 36^{\prime} \mathrm{E}$ & Lindi & - & & & & & Rituals and Shrine \\
\hline Mtumbei kitabi & $8^{\circ} 19^{\prime} \mathrm{S} / 38^{\circ} 55^{\prime} \mathrm{E}$ & Lindi & & & & $\bullet$ & & $\begin{array}{l}\text { Hanging site } \\
\text { Mass grave }\end{array}$ \\
\hline Somanga & $8^{\circ} 25^{\prime} \mathrm{S} / 39^{\circ} 16^{\prime} \mathrm{E}$ & Lindi & - & & & & & $\begin{array}{l}\text { German agent res. } \\
\text { Settler plantation }\end{array}$ \\
\hline Nyangao & $10^{\circ} 20^{\prime} \mathrm{S} / 39^{\circ} 17^{\prime} \mathrm{E}$ & Lindi & - & & & & & $\begin{array}{l}\text { Destroyed church } \\
\text { Sister death site }\end{array}$ \\
\hline
\end{tabular}




\begin{tabular}{|c|c|c|c|c|c|c|c|c|}
\hline \multirow[t]{2}{*}{ Site } & \multirow[t]{2}{*}{ Location } & \multirow[t]{2}{*}{ Region } & \multicolumn{5}{|c|}{ Battlefield landscape } & \multirow[t]{2}{*}{ Type } \\
\hline & & & $\begin{array}{l}\text { Coastal/ } \\
\text { estuarine }\end{array}$ & Hilltop & Urban & Low land & Memorial & \\
\hline Liwale & $09^{\circ} 47^{\prime} \mathrm{S} / 37^{\circ} 55^{\prime} \mathrm{E}$ & Lindi & & & & $\bullet$ & $\bullet$ & $\begin{array}{l}\text { German boma } \\
\text { Rubber Plantation } \\
\text { Bishop Death site }\end{array}$ \\
\hline Lukuledi & $10^{\circ} 33^{\prime} \mathrm{S} / 38^{\circ} 48^{\prime} \mathrm{E}$ & Mtwara & $\bullet$ & & & & & Destroyed church \\
\hline Lulindi & $10^{\circ} 48^{\prime} \mathrm{S} / 39^{\circ} 10^{\prime} \mathrm{E}$ & Mtwara & & & & $\bullet$ & & Resisted Majimaji \\
\hline Mititimo & $10^{\circ} 30^{\prime} \mathrm{S} / 39^{\circ} 1^{\prime} \mathrm{E}$ & Mtwara & & & & $\bullet$ & & Destroyed school \\
\hline
\end{tabular}


resting on variously recalled events, interactions and processes that have shaped the constituencies of modern group (Adler and Bruning 2008). The identity of the society and war is much related thus a fully understanding of Majimaji is impossible without the understanding of the societies (Gwassa 1969). Majimaji war peoples were the inhabitants of southern Tanzania. The people of southern Tanzania are migrants from different parts of southern Africa. Others trace their origin form South Africa (e.g., the Ngoni); others from Malawi (e.g., the Makua and Mwera); others from Mozambique (e.g., the Makonde); and others from a mixture of the extant southern Tanzania ethnic groups such as Makonde, Ngoni, Hehe, Makua and Mwera (e.g., the Matumbi).

Any serious understanding of a social group's identity rests in part on interpretations of the group's origins. This means delving into the historic foundations of how the group came to its present location and situation as well as familiarizing oneself with the potentially vast array of material and symbolic evidence that the group refers o in supporting its links to the past. The material and conceptual evidence supporting group coherence and continuity coexist, providing a nexus for the formation, reformation and reproduction of social identities at the individual, community, tribal, regional and national levels (Adler and Bruning 2008:36). Material culture, especially pottery support the Majimaji peoples similarities in tradition and uses. There is no variation in pottery types collected during survey and excavation throughout the Majimaji landscape. Locally produced, domestic ceramics are understood as products of economic and socio-cultural local traits, ideal for identifying continuities and changes. Commonalities of ceramic forms and decorative grammars are often equated with cultural similarities, evidence of common experiences for groups of people, including assumptions of common ethnicities that can be observed across time and space. However, historical changes that occurred over a short time period may influence the production and consumption of material culture; particularly ceramics, as well as producers' choice and agency, technological and decorative styles (Cruz 2011). The relationship between material culture and identity is ambiguous and extremely fluid (Hodder 1982). Throughout the Majimaji war zone, ceramic vessels, identical in form and decoration, are used by different groups in their daily life. When analyzed at a micro-level, their manufacture varies only slightly from village to village, but never from ethnic group to ethnic group (see Figure 2).

Nevertheless, the consideration of the people of Southern Tanzania as new comers has been challenged by archaeologists. The argument is that there were no population settled in the south before the Early Iron Working communities (Kwekason 2011). However, lithic materials of as early as Middle Stone Age were recovered in sites of Lulindi. This evidence suggests that the people who moved into southern Tanzania in the mid-second 


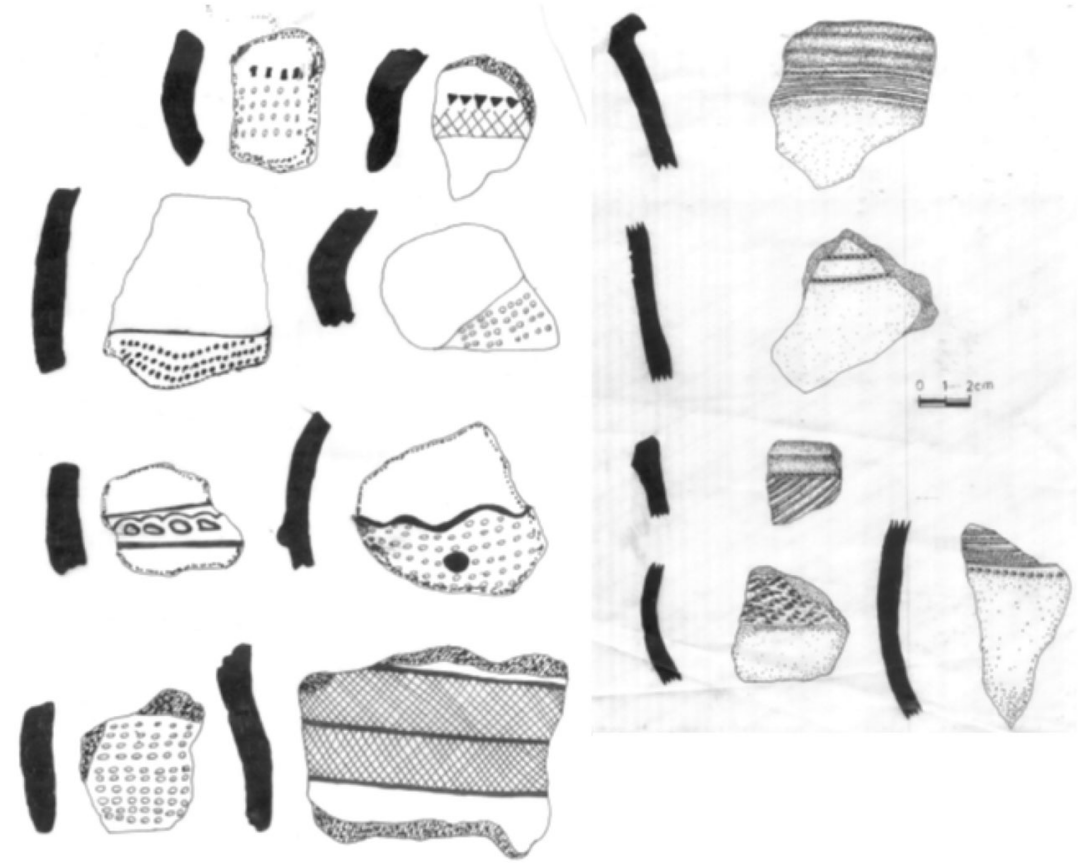

Figure 2. Early iron working pottery from Southern Tanzania

millennium A.D. dispersed and settled in various areas where later Majimaji war occurred were not immigrating into empty landscapes. As they entered the area, it is fairly certain that the area was inhabited by Stone Age and Early Iron Age groups attested to the material culture discovered under this research. Also, the people of southern Tanzania have myths of encounters with little people who are associated with the Stone Age culture (Saetersdal 1999) (Figure 3).

\section{Majimaji War Landscapes}

Landscape is lined to the identity of its inhabitants (Knapp and Ashmore 2000:14). People recognize, inscribe and collectively maintain certain places or regions in ritual, symbolic or ceremonial terms; conversely, these places create and express social cultural identity. Thus, cultural landscapes are mnemonic devices for identity (Keremedjiev 2013). In studying the Majimaji resistance, the war landscape offers an opportunity to examine both the physical and symbolic aspects important to understand the identity of the war. There is a connection between landscape, people, place, the past 

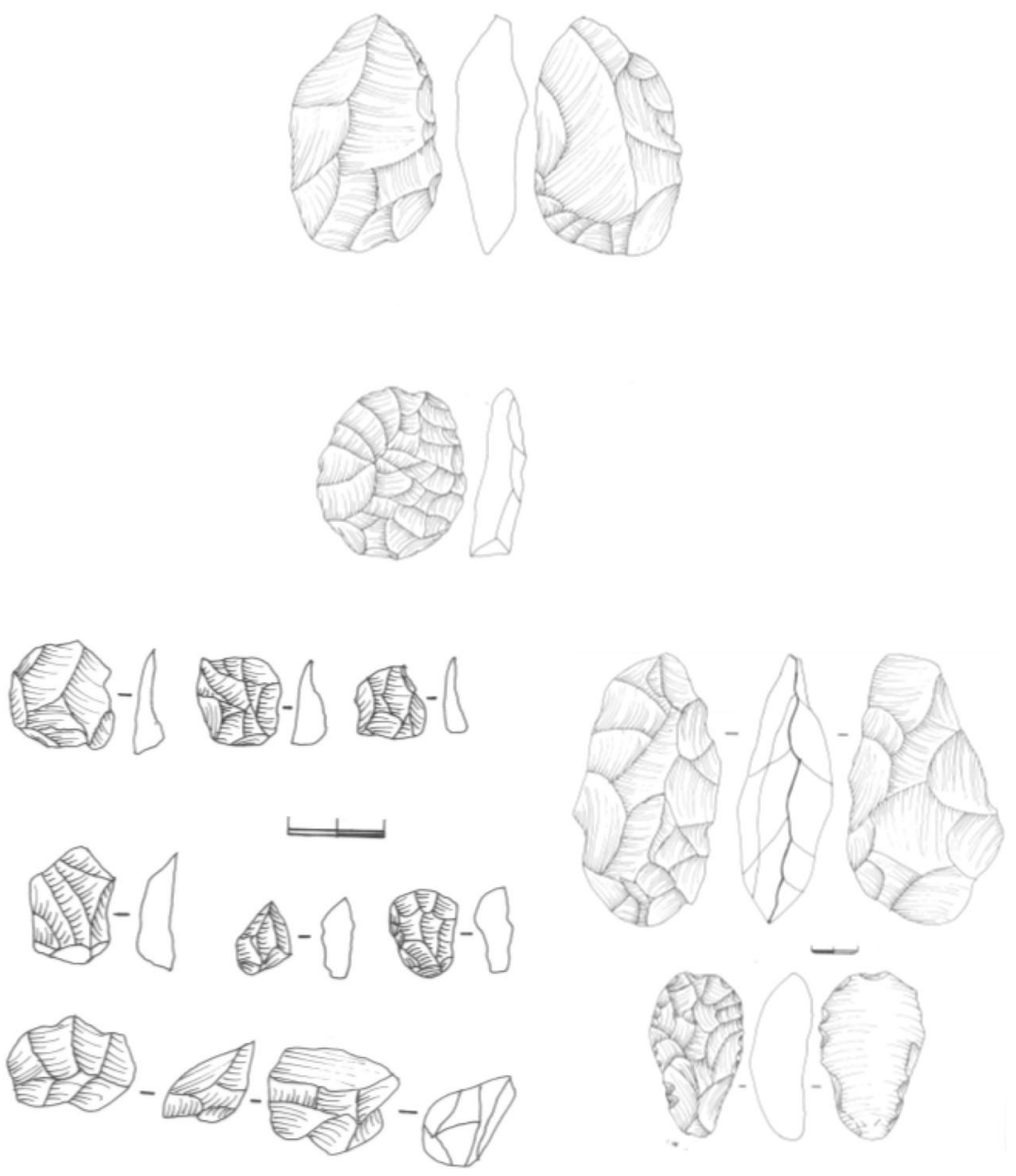

Figure 3. Lithic materials from Southern Tanzania

and the present (Brown and Bowen 1999). Landscape is useful for identifying settlement locations in relation to defence and defensive measures; battle site; and refuge. Thus, the archaeological investigation of Majimaji primarily relied on landscape as the material evidence of the war.

Settlement is sometime a defensive strategy (Lambert 2002). The origin of the Majimaji war was in landscapes which were defensive in nature. Matumbiland for example is in hills which allow visibility of an enemy from afar and prepare for attack or hide while Ngarambi is in proximity to forests. The two sites were very important for the Majimaji war. The Matumbi ignited the war while Ngarambi was a ritualistic and military 
training landscape in preparation of the war. Also, the Matumbi landscape has numerous caves which were used for refuge purposes. The Nang'oma cave for example which is one of the largest caves in Africa and Namaingo, which has stream of water running inside, was ideal for refuge. Nandete is commemorated with a memorial constructed onsite to perpetuate the memories of the war in the Matumbiland. A dispensary has also been established in the same site which provides medical services to the people.

The survey of Ngarambi observed pottery on the surface and an earthen mound of a collapsed house indicating an abandoned settlement of Kinjekitile Ngwale. The site is still used by ritualists who want to appeal to more power and healing. Kinjekitile is also associated with the Ngarambi pool which was the source of the water concoction (Gwassa 1969:261). The archaeological survey of Ngarambi discovered two different systems of water associated with Kinjekitile, but both of them had no features of a pool. The first one was presented by the local informants as Kinjekitile natural spring. It is an area with underground water, clear and clean white. According to the local informants, Kinjekitile used this spring for drinking water. The spring never dries. Since it is in the village reserve area today which is far from the local village settlement, the spring is only used during farming season when some farms are extended to the area. The second system of water associated with Kinjekitile is the river confluence of rivers Ngarambi and Namangondo. According to oral informants, the bedrock of this river was used as by Kinjekitile when he was administering maji. Kinjekitile residence is located $5 \mathrm{~m}$ from the river. According to the local informants, the people of Ngarambi cherished the memories of Kinjekitile. Since there is no any memorial installed at the site, since 1970s-1990s, the students of Ngarambi primary school used to host their graduation ceremonies at this place. Currently, the graduation is hosted at school but the sub village which Kinjekitile lived and where all the sites attributed to him are located is known as Kinjekitile sub village. This toponymic memorial has been very important, especially in the absence of constructed memorial.

The powerful Majimaji warriors were associated not only with military prowess but also ritual practices. According to the local informants, these leaders had abilities to turn the warriors into termite mounds, to bees or disappear. The strong holds of these leaders have therefore been turn to ritual sites. At Chandamali for example, which according to the local informants was both a refuge and military basement for the war general Songea Mbano of Ngoniland, the modern traditional healers are using the site for witchcraft and ritual ceremonies (see Figure 4). The area is sometimes confused as the residential area for chief Songea. Survey of the area indicated that the cave is small to be a chief residence but suitable for refuge. The 


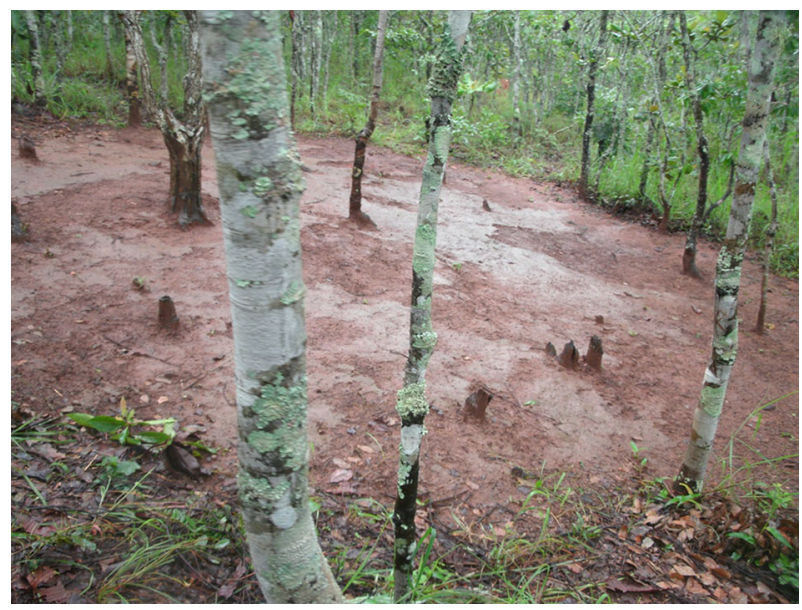

Figure 4. A contemporary ritual site near Chandamali cave

cave has a lot of pseudo entries which allows crawling at the entry blocked after 2-3 m inwards. This can confuse the enemies. The true entry is at the western point of the cave. It allows crawling at the end, bending after $3 \mathrm{~m}$ and standing after $5 \mathrm{~m}$. The ceremonies are accompanied with sacrifices mostly poultry as observed during survey. The Majimaji council of elders responsible for the custodian of the Majimaji heritage is not in favour of the witchcraft tradition merged into the Majimaji heritage. Although they acknowledge that the ritual ceremonies of the witches are associated with the strength of Songea Mbano, they are against pollution of environment which conflict with their Majimaji tourism goal.

\section{Majimaji War Weaponry}

Weaponry offers important insights into the conduct of war. They account for the close hand-to-hand combat or a distance fight (Lambert 2002). According to the local informants, the weapons used for fighting throughout the Majimaji region were of the same nature. Africans used stones, spears, sticks, knife, shield, bow and arrows. African warriors also used guns. According to Makweta (1968:2) some of those who fought during Majimaji used the guns as Europeans. The use of guns among Africans was very minimal while the Germans weapons were guns. This research recovered a bullet cover at the Nyangao site. The First World War affected parts of the Majimaji war areas. Battles like Lukuledi, Nyangao, Kibata, Mtumbei and Namabengo are some of these sites. These sites have also ditches and 


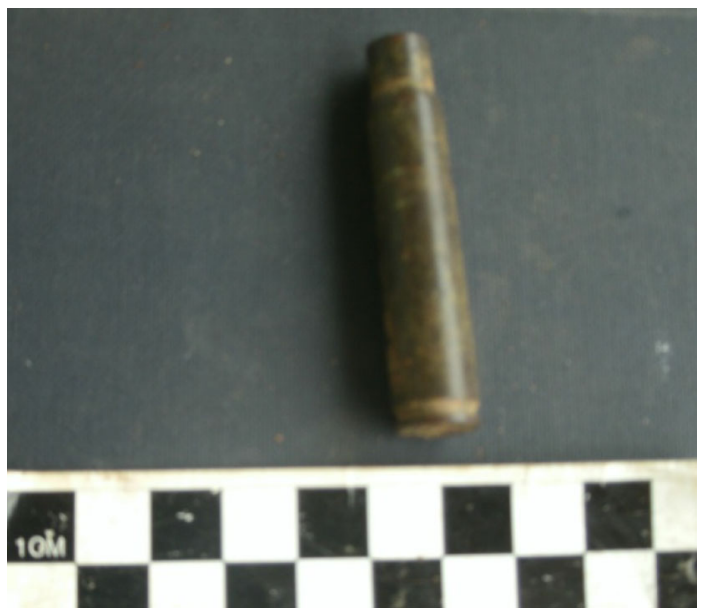

Figure 5. A bullet cover from Nyangao

trenches which are typical features of the First World War rather than the Majimaji War. The ditches measured approximately $10 \mathrm{~m}$ across; lying parallel to the hill in one escarpment of the River Nyangao. The analysis of the bullet cover (Figure 5) represented a British gun which was not part of the Majimaji war but the First World War. Other Majimaji war weapons are displayed in the Majimaji museum.

In Nyangao site, the First World War memories are recalled than the Majimaji ones. This is because the Majimaji impacts have remained in tales while the First World War is still experienced physically in their environment. The people encounter bullet in their agricultural activities and several incidences of bombs which blast and kill until very recent. A case was mentioned where an iron smith took home a bomb. To him, it was a heavy metal which he intended to heat and smith. Upon heating, the bomb killed him on the spot. The memories of the German wars and colonization are thus traumatic among the communities of southern Tanzania.

\section{The Identity of the Warriors}

Majimaji warriors were men and women commonly organized on the basis of clans. In Majimaji studies, very little attention has been devoted to the female warriors. However, in both traditional and modern security systems, women have been very important agents (Kirk and Okazawa-Rey 2007). The security system of many societies and countries at large requires women support and participation in many capacities. The society needs 
nurses (traditionally bio-medicine technicians) to heal the wounded and traumatized. They also need wives and girlfriends back home, the prize waiting at the end of war, women who live with veterans or mourn loved ones killed in action.

It is therefore important to demonstrate with evidence that in particular time and space warriors were either male or female (Hays-Gilpin and Whitley 1998). Consequently, different methods will be appropriate for identifying agencies and developing convincing interpretations in different context (Johnson 2002:214). As archaeology looks at the material evidence, one of the major concerns is to understand how gender is affected by and uses material objects (Sørensen 2000). Historians have explained how women were exchanged as security during the Majimaji war (Monson 1998) and assumed greater authority over fields previously designated as the domain of men (Sunseri 1997:257). Nkomanile who was a woman sub chiefs in Ngoniland has been discussed widely but the discussion has been limited to the induction of the war in the south western regions through Omari Kinjala (Illife 1967; Mapunda and Mpangara 1969; Schmidt 2010). This leave a lacunae in other aspects of this warrior including Kitanda as a gendered site, the burial of this female warrior with other male in the mass grave and an opposition to the common emphasis on both physical and emotional differences between men and women, associating the former with strength, aggression and violence and the later their opposite.

Majimaji warriors were predominantly male with bottles of maji, blue or black cloth and a headband threaded with stalks of millet or maize on the forehead. However, throughout the Majimaji war, women were involved in different context. According to the local informants, among the Matumbi of Nandete, Jumbe (German local representative) Mtemangani sent a letter to his superior at Kibata through his wife Namchanjama. This was after all his immediate officers including Mtemangani himself disagree to take the letter in fear of the reaction. Namchanjama was to report to the Akida (senior German local representative) Seif bin Amri at Kibata German administrative offices. Namchanjama was killed at Imbiliya hill upon her return to Nandete on a fiercest battle between the German representatives at Kibata and Matumbi warriors. Namchanjama was among the first people who were killed during the Majimaji war.

Non-combatants such as women are as much a factor as armies, formal or informal (Hill and Wileman 2002). The war medicine (maji) for example was sometimes administered by women who were a substantial, integrated element in ritual activities and in war (Monson 2010). While men used the war medicines to ensure the accuracy of firearms, women took medicines to strengthen them against the hardship of flight into woodland hiding places and preserve them from capture by enemies (Giblin and Monson 2010). Women were also used as spies for this reason colonial 
troops detained women as hostages in order to establish whether they were Majimaji supporters or loyalists. This technique intended to force surrender by preventing supplies reaching the warrior bands but also acknowledged the important role women played during the warfare (Schmidt 2010).

\section{Conclusion}

The identity of the Majimaji war as a national epic created by the local people and nationalist historians presented the war as the landmarks of oppression and relative promises of freedom (Fennell 2010). However, in the creation of the same identity, different groups acknowledge themselves as the prominent actors of this liberation than other. The modern day Muslims for instance are seeking recognition for their longstanding availability in the region and their participation in the making of Tanzania as a country (Abdallah 2011). Missionaries were accused by the German administrators not controlling the movement as they were very close to the local people yet they did not discover the movement until they were attacked. Their establishment of the war identity in their accounts is very defensive to avoid any evidence for Christianity being the factor for the outbreak of the Majimaji war. The historical study of colonialism needs to be further developed to fully acknowledge the extent of shared space, knowledge, and experience between colonizers and colonized (Schmidt 2008) so as to establish the identity of one over the other. The approach to the study should also involve different fields other than history so as to explore other aspects of the war. Among the points upon which most researchers agree is the importance of heritage sites in creation of identity (Garden 2008:270). Archaeological studies which include material and landscape parameters as part of the study inform more on different aspects which would otherwise remain obscured. The memories of the war in the contemporary societies vary in a great deal. There are battle sites which are memorized while others have combined the colonial situation as the European calamities. While forgetting colonialism is Southern Tanzania is impossible, the unavailability of memorials in a vast area has narrowed the significance of the war in the region rendering the extant generation limited of the war memories. In some societies, the local peoples have created psychological memorials over the landscape and even toponymic memorials. The German boma (headquarters) for example are considered as graves for most of the Majimaji warriors because those who were arrested and prosecuted were hanged and never buried by the people. The colonial plantations represent the causes of the war. The cotton plantation at Nandete which has a memorial stands as a symbol of other colonial projects in southern 
Tanzania. The Majimaji battle sites represent not only the identity of the war but how the war is memorized by the contemporary people of the affected region.

\section{References}

Abdallah, H.B.

2011. Jihadi Kuu ya Majimaji 1905-1907. Sayofa Limitted, Dar es Salaam.

Adler, M., and S. Bruning

2008. Navigating the Fluidity of Social Identity: Collaborative Research into Cultural Affiliation in the American Southwest. In Collaboration in Archaeological Practice, edited by C. Colwell-Chanthaphonh and T.J. Ferguson, pp. 35-54. Altamira Press, New York.

Alexander, N. R.

2008. Archaeological Evidence of the Maji Maji War in Matumbiland, Southeastern Tanzania. Unpublished B.A. Dissertation, University of Dar es Salaam, Dar es Salaam.

Becker, F.

2004. Traders, 'Big Men' and Prophets: Political Continuity and Crisis in the Maji Maji Rebellion in Southeastern Tanzania. The Journal of African History 45(1):1-22.

Beez, J.

2004. Geschosse zu wassertropfen sozio-religiöse aspekte des Maji-Maji-Krieges in Deutsch-Ostafrika (1905-1907). The International Journal of African Historical Studies 37(1):141-143.

Bell, R.M.

1950. The Maji Maji Rebellion in Liwale District. TNR 28:38-57.

Brown, M., and P. Bowen

1999. The Last Refuge of the Faeries: Archaeology and Folklore. In Archaeology and folklore, edited by A Gazin-Schwartz and C Holtorf, pp. 255-273. Routledge, London.

Burström, M.

2009. Selective Remembrance: Memories of a Second World War Refugee Camp in Sweden. Norwegian Archaeological Review 42(2):159-172.

Cruz, M.D.

2011. Pots are Pots, Not People: Material Culture and Ethnic Identity in the Banda Area (Ghana), Nineteenth and Twentieth Centuries. Azania: Archaeological Research in Africa 46(3):336-357. 
Ebner, E.

2009. The History of the Wangoni. Benedictine Publication, Ndanda \& Peramiho.

Fennell, C.C.

2010. Carved, Inscribed, and Resurgent: Cultural and Natural Terrains as Analytic Challenges. In Perspectives from Historical Archaeology: Revealing Landscapes Society for Historical Archaeology, edited by CC Fennell, pp. 111. University of Arizona Press, Arizona.

Garden, M.C.

2008. "The Heritage Space: Looking at Heritage Sites". In Heritage Studies: Methods and Approaches, edited by M. Sørensen and J. Carman, pp. 270291. Routledge, New York.

Giblin, J., and J. Monson (editors)

2010. Maji Maji: Lifting the Fog of War. Leiden, Boston.

Gilchrist, R.

2003. Introduction: Towards a Social Archaeology of Warfare. World Archaeology 35(1):1-6.

Greenstein, E.

2010. Making History: Historical Narratives of the Maji Maji. Penn History Review 17(2):60-77.

Gwassa, C.K., and J. Illife

1969. Records of the Maji Maji rising. Historical Association of Tanzania, Dar es Salaam.

Gwassa, G.C.K.

1969. African Methods of Warfare During Maji Maji War 1905-1907. Social Science Council of the University of East Africa 1:256-272.

1973. The Outbreak and Development of the Maji Maji War, 1905-1907, PhD Thesis, University of Dar es Salaam.

Hays-Gilpin, K., and D. Whitley

1998. Introduction: Gendering the Past. In Reader in Gender Archaeology, edited by K. Hays-Gilpin and D.A. Whitley, pp. 3-10. Rouletdge, London.

Herbst, J.

1989. The Creation and Maintenance of National Boundaries in Africa. International Organization 43(4):673-692.

Hill, P., and J. Wileman

2002. Landscapes of War: The Archaeology of Aggression and Defense. Tempus Publishing, Stroud.

Hodder, I.

1982. Symbols in Action: Ethnoarchaeological Studies of Material Culture. Cambridge University Press, Cambridge. 
Iliffe, J.

1979. A Modern History of Tanganyika, African Studies Series. Cambridge University Press, Cambridge.

1967. The Organization of the Maji Maji Rebellion. Journal of African History 8(3):495-512.

Johnson, M.

2002. Self-Made Men and Staging of Agency. In Agency in Archaeology, edited by M Dobress, and J Robb, pp. 213-231. Routledge, London.

Jones, A.

2002. Archaeological Theory and Scientific Practices. Cambridge University Press, Cambridge.

Kamanga, K.C.

2009. The Maji Maji War: An International Humanitarian Law Perspective. Journal of Historical Association of Tanzania 6(2):47-65.

Keremedjiev, $\mathrm{H}$.

2013. The Ethnography of On-Site Interpretation and Commemoration Practices: Place-Based Cultural Heritages at the Bear Paw, Big Hole, Little Bighorn, and Rosebud Battlefields, PhD Dissertation, University of Montana, Missoula.

Kirk, G., and M. Okazawa-Rey

2007. Women's Lives: Multicultural Perspectives. McGraw-Hill, Boston.

Knapp, A.B., and W. Ashmore

2000. Archaeological Landscapes: Constructed, Conceptualized, Ideational. In Archaeologies of Landscape, edited by W. Ashmore, and A.B. Knapp, pp. 1-32. Blackwell, Oxford.

Kwekason, A.

2011. Holocene Archaeology of the Southern Coast of Tanzania. E\&D Vision Publishing, Dar es Salaam.

Lambert, P.M.

2002. The Archaeology of War: A North American Perspective. Journal of Archaeological Research 10(3):207-241.

Lane, $\mathrm{P}$.

2011. Possibilities for a Postcolonial Archaeology in Sub-Saharan Africa: Indigenous and Usable Pasts. World Archaeology 43(1):7-25.

Larson, L.

2010. The Ngindo: Exploring the Center of the Maji Maji Rebellion. In Maji Maji: Lifting the Fog of War, edited by J. Giblin, and J. Manson, pp. 71113. Leiden, Brill.

Lawi, Y.

2009. Pros and Cons of Patriotism in the Teaching of the Maji Maji War in Tanzania Schools. Journal of Historical Association of Tanzania VI.2:66-90. 
Libaba, P.M.

1968. The Maji Maji Rising in Lindi district. University of Dar es Salaam, Dar es Salaam.

Linger, D.T.

2005. Identity. In A Companion to Psychological Anthropology, edited by C. Casey, and R. Edgerton, pp. 185-200. Blackwell, Oxford.

Lyons, J.

1968. Introduction to Theoretical Linguistics. Cambridge University Press, London.

Makweta J.

1968. Majimaji in Ubena, Majimaji Research Project No. 4/68/1/1.

Malande, J.

2011. Language and Linguistics Theory. Yoms, Dar es Salaam.

Mapunda, B.

2010. Re-examining the Maji Maji War in Ungoni with a Blend of Archaeology and Oral History. In Maji Maji: Lifting the Fog of War, edited by J. Giblin, and J. Manson, pp. 220-238. Leiden, Brill.

Mapunda, O.B., and G.P. Mpangara

1969. The Maji Maji War in Ungoni. East African Publishing House, Dar es Salaam.

Monson, J.

1998. Relocating Maji Maji: The Politics of Alliance and Authority in the Southern Highlands of Tanzania, 1870-1918. The Journal of African History 39(1):95-120.

2010. War of Words: The Narrative Efficacy of Medicine in the Maji Maji War. In Maji Maji Lifting the Fog of War, edited by J. Giblin, and J. Monson, pp. 33-69. Brill, Boston.

Moyd, M.

2010. All people were Barbarians to the askari....: Askari Identity and Honor in the Maji Maji War, 1905-1907. In Maji Maji Lifting the Fog of War, edited by J. Giblin, and J. Monson, pp. 149-179. Brill, Boston.

Njogu, K., A. Mwihaki, and A. Bulika

2006. Sarufi ya Kiswahili, Uchanganuzi na Matumizi . Jomo Kenyatta Foundation, Nairobi.

Nyerere, J.K.

1967. Freedom and Unity. Oxford University Press, Dar es Salaam.

O’Grady, W., M. Dobrovolsky, and F. Katamba

1996. Contemporary Linguistics. Longman, London.

Ombuchi, S., and A. Mukhwana

2010. Muundo wa Kiswahili Ngazi na Vipengele. A-Fame, Nairobi. 
Pesek, M.

2007. The Boma and the Peripatetic Ruler: Mapping Colonial Rule in German East Africa, 1889-1903. Western Folklore 66(3):233-257.

Saetersdal, T.

1999. Symbols of Cultural Identity: A Case Study from Tanzania. The African Archaeological Review 16(2):121-135.

Scheper-Hughes, N.

2005. The Politics of Remorse. In Companion to Psychological Anthropology, edited by C. Casey, and R.A. Edgerton, pp. 469-494. Blackwell, Oxford.

Schmidt, $\mathrm{H}$.

2010. A Deadly Silence Predominated in the District: The Maji Maji War in Ungoni. , pp. 183-220Brill, Leiden.

Schmidt, H.I.

2008. Colonial Intimacy: The Rechenberg Scandal and Homosexuality in German East Africa. Journal of the History of Sexuality 17(1):25-59.

Sørensen, M.

2000. Gender Archaeology. Blackwell, Oxford.

Stollowsky, O., and J.W. East

1988. On the Background to the Rebellion in German East Africa in 1905-1906. The International Journal of African Historical Studies 21(4):677-696.

Sunseri, T.

1997. Famine and Wild Pigs: Gender Struggles and the Outbreak of the Maji Maji War in Uzaramo (Tanzania). The Journal of African History 38(2):235-259.

1999. Majimaji and the Millennium: Abrahamic Sources and the Creation of a Tanzanian Resistance Tradition. History in Africa 26:365-378.

2010. The War of the Hunters: Maji Maji and the Decline of the Ivory Trade. In Maji Maji: Lifting The Fog of War, edited by J. Giblin, and J. Manson, pp. 117-148. Leiden, Brill.

Tidy, M., and D. Leeming

2001. A History of Africa 1840-1914. Arnold Publisher, London. 